\author{
온실가스 감축컨설팅 우수기업 지정제 제도화방안 연구 \\ 임기추 \\ 에너지경제연구원 \\ (2013년 9월 30일 접수, 2013년 12월 13일 수정, 2013년 12월 13일 채택)
}

\title{
A Study on the Measure to Implement Certification Scheme for Consulting Company to Reduce GHG
}

\author{
Ki Choo, Lim \\ Korea Energy Economics Institute
}

(Received 30 September 2013, Revised 13 December. 2013, Accepted 13 December 2013)

$$
\text { 요 약 }
$$

온실가스-에너지 목표관리제 시행에 따라 대상기업 및 사업장에서는 온실가스 배출량 및 에너지 사용 량 명세서, 목표관리 이행계획서 및 실적(온실가스 감축 잠재량.실적의 검증) 보고서 작성 등 당면과제 가 놓여 있다. 따라서 관련 컨설팅 기업들이 대상기업의 감축목표를 달성하기 위하여 온실가스 감축시 스템을 구축하고 실행하도록 유도하기 위한 방안의 하나로 우수기업 지정제와 같은 제도의 도입이 요청되고 있다. 본고에서는 온실가스 감축컨설팅 우수기업 지정에 관한 방안이 원활하게 시행되기 위 한 제도화 방안으로 지정대상, 평가절차, 평가기준의 설정 및 평가기관의 평가위원회 구성 등 대안을 제시하였다.

주요어 : 온실가스, 컨설팅, 우수기업 지정제, 제도화

\begin{abstract}
The certification scheme for best company has been implementing in order to stimulate the investment of private consulting company to reduce GHG emission. This study was conducted to set up the certification scheme, to suggest process, criterion, institute, committee which are necessary for the evaluation of certificate. Evaluation process for the introduction of the certification scheme is divided into 7 successive phases, (1) Certificate application(Applicant $\rightarrow$ Certification Institute), (2) Evaluation request(Certification Institute $\rightarrow$ Evaluation Institute), (3) Accept and document review(Evaluation Institute), (4) Site and document evaluation(Evaluation Institute $\rightarrow$ Evaluation committee), (5) Sending evaluation result(Evaluation Institute $\rightarrow$ Certification Institute), (6) Certification confirmation (Certification Institute), (7) Issue of certificate(Certification Institute $\rightarrow$ Applicant).
\end{abstract}

Key words : GHG, consulting, certification scheme for company

\section{1. 서 론}

정부는 국가 온실가스 감축목표를 달성하기 위하 여 비용효과적인 감축정책을 도입하고 산업부문의 국 제경쟁력 및 투자 등을 반영한 부문별 감축목표 설정

\footnotetext{
${ }^{\dagger}$ To whom corresponding should be addressed.

Korea Energy Economics Institute, Uiwang 437-713, Korea

Tel : 031-420-2295 E-mail : kclim@keei.re.kr
}

을 추진하며, 부문별 감축목표를 기반으로 부문별 온 실가스-에너지 목표관리제를 도입하였다 [1]. 「저탄소 녹색성장 기본법」제42조에 의거하여 2012년부터 목 표관리제를 시행 중이며, 2010년 9월에 471개의 기 업과 공공기관 등을 관리대상으로 지정한 바 있다. 이중 산업.발전분야의 경우 업체(법인) 167 개, 사업장 208 개 등 총 375 개 관리업체가 지정되었다. 2014년 
에 산업·발전분야 관리대상은 520 여개로 확대 지정될 전망이다 [13,11].

관리 대상기업 및 사업장에서는 온실가스 배출량 및 에너지 사용량 명세서, 목표관리 이행계획서 및 실적(온실가스 감축 잠재량-실적의 검증) 보고서 작 성 등 당면과제가 놓여 있다. 국내에서는 온실가스 감축컨설팅 관련 에너지진단전문기업, 에너지절약전 문기업(ESCO) 및 관련 컨설팅 업체들이 관련 업무를 수행하고 있는 상황이다 $[12,8]$.

온실가스 감축과 관련한 국내 컨설팅업계에서는 대상기업의 배출량 조사 및 인벤토리 구축, 온실가스 배출계수 개발, 국가 온실가스 감축사업과 관련한 메 커니즘 개발 등 온실가스 감축기반 구축관련 업무를 수행하고 있다 [4]. 따라서 관련 컨설팅 기업들이 대 상기업의 감축목표를 달성하기 위하여 온실가스 감축 시스템을 구축하고 실행하도록 유도하기 위한 방안의 하나로 우수기업 지정제와 같은 제도의 도입이 요청 되고 있다 [8].

본고에서는 온실가스 감축컨설팅 기업에 대한 우 수기업 지정제 도입을 위한 제도화 방안을 강구하는 데 목적이 있다. 이러한 목적에 입각한 본고의 주요 내용은 다음과 같다. 먼저 온실가스 감축컨설팅 기업 관련 지정사례를 살펴보고, 정책 및 업계관계자 자문 을 통해 온실가스 감축컨설팅 기업에 대한 우수기업 지정제의 제도화 방안을 제시하고자 한다.

\section{2. 온실가스 감축컨설팅 기업관련 지정사례}

\section{2-1. 우수 $\mathrm{ESCO}$ 지정사례}

2-1-1. 우수 $\mathrm{ESCO}$ 선정제도 추진현황

우수 $\mathrm{ESCO}$ 선정제도는 에너지절약전문기업 관리 규정 제 17 조에 의거해 우수 $\mathrm{ESCO}$ 인증이 시행되었 으나, 2011년 2월 전문 $\mathrm{ESCO}$ 지정제가 도입되면서 폐지되었다 [6]. 우수 $\mathrm{ESCO}$ 에 대한 선정은 2006년 에 4개 기업, 2007년 이후 2010년 까지 매년 2개 기 업이 선정되었다 $[6,7]$

우수 $\mathrm{ESCO}$ 선정제의 목적은 에너지절약에 실질적 으로 기여한 $\mathrm{ESCO}$ 를 우수 $\mathrm{ESCO}$ 로 인증함으로써 $\mathrm{ESCO}$ 사업의 발전도모 및 건실한 $\mathrm{ESCO}$ 를 육성하 는 데 있었다. 대기업 및 중소기업으로 구분하여 각 각 1 개 기업을 선정하여 3 년간 우수 $\mathrm{ESCO}$ 선정업체 로서의 자격을 가질 수 있다. 우수 $\mathrm{ESCO}$ 선정업체로 인증되면 우수 $\mathrm{ESCO}$ 인증서를 부여하고, 자금지원
시 인센티브 부여 및 $\mathrm{ESCO}$ 투자사업 적격심사 시 가산점 $(+1)$ 이 부여되었다 [7].

\section{2-1-2. 우수 ESCO 선정기준 및 평가}

우수 $\mathrm{ESCO}$ 선정은 신청을 받고 서류 및 현장심사 를 거친 후 종합심사를 하여 선정하였다. 우선 서류 심사는 평가항목 및 배점기준에 의해 정량적 심사를 통해 우수 $\mathrm{ESCO}$ 규모의 3 배수 이내로 선정하며, 현 장심사는 서류심사를 통과한 $\mathrm{ESCO}$ 에 대해 현장방문 을 통해 제출서류의 적합성 여부를 확인하고 심사하 였다. 그리고 종합심사는 인증위원회에서 업체별 발 표내용을 참고하여 종합심사 평가표에 따라 위원별 개별 평가를 실시하여 3 배수 이내로 선정한다.

인증위원회는 총 10 인 이내로 구성하여 서류심사 및 현장심사를 통과한 $\mathrm{ESCO}$ 에 대해 종합심사기준에 따라 심사하였다. 평가항목은 사업수행 실적(35점), 경영상태(20점), 고객만족도(15점), 기술능력(15점), 정책 참여도(15점) 등 100 점 만점 기준이다. 위원장 은 산업통상자원부(담당관), 에너지관리공단(기술컨 설팅·효율관리업무), $\mathrm{ESCO}$ 협회(부회장)로 구성된 당 연직 위원 3 명, 에너지절약기술 관련분야 전문가가 포함된 위촉직 위원 6 명 등으로 구성된다. 현장심사 를 포함한 서류심사 점수를 $50 \%$ 반영하고 인증위원 회 종합심사 점수를 $50 \%$ 반영하여 최종 우수 $\mathrm{ESCO}$ 를 선정하였다 [7].

\section{2-2. 녹색기업 지정사례}

\section{2-2-1. 녹색기업 제정제 추진현황}

녹색기업 지정제는 기존의 규제 중심적 환경정책 에서 벗어나 기업 스스로가 환경성을 평가하고 개선 계획을 실행하도록 하여 사업장의 자율적 환경관리체 제를 구축하기 위해 도입되었다. 「저탄소 녹색성장 기본법」 시행(2010.4)에 따라 기존 '환경친화기업' 명칭이 ‘녹색기업’으로 변경된 것이다.

녹색기업은 오염 물질의 현저한 저감, 자원 및 에 너지의 절감, 제품의 환경성 개선, 환경경영체제의 구 축 등을 통하여 환경개선에 크게 기여하는 사업장으 로 환경부장관이 지정한 사업장을 말한다. 녹색기업 지정기간은 「환경기술 및 환경산업 지원법, 개정에 따라 신규 지정기간 및 재지정 기간 모두 3 년으로 규 정하고 있다. 자격요건은 국내 소재 기업 중 최고경 영자의 환경친화적 기업경영 의지를 바탕으로 전 조 
직원 참여 하에 오염물질의 적정처리 뿐만 아니라 사 전예방적 환경관리와 환경개선을 적극적으로 수행하 는 기업이어야 한다. 그러나 지정 신청일 기준 과거 2 년 이내에 환경법령 위반으로 「환경기술개발 및 지 원에 관한 법률」 시행령 제 22 조의 7(지정취소) 사유 에 해당되는 경우, 지정 신청일 기준 과거 1 년간 대 기 - 수질분야 평균 배출농도가 「환경친화기업 지정 제도 운영규정」에서 정하고 있는 강화기준을 준수하 지 못한 경우(중소기업 제외)에 자격이 제한된다 [15].

녹색기업 지정현황을 보면 1995년부터 현재까지 꾸준히 운영되어, 지정받은 사업장 수는, 제도가 시작 된 1995년 28개에서 2012년 현재 총 207개로 늘어 났다. 현재 녹색기업은 대기업 $95.4 \%$, 중소기업 $4.6 \%$, 제조업 $97.4 \%$, 비제조업 $2.6 \%$ 로, 대기업 및 제조업이 다수를 차지한다 [16]. 녹색기업 지정에 따 른 인센티브는 「대기환경보전법」및「수질 및 수생태 계 보전에 관한 법률 에 따른 배출시설 설치허가를 신고로 대체, 「대기, 수질, 소음-진동, 폐기물 및 유해 화학물질 등 환경관련 법률」에서 규정하는 보고 검 사사항의 면제, 환경개선사업 소요자금 및 기술지원 우대 조치 등이 부여되고 있다 [15].

\section{2-2-2. 녹색기업 평가}

녹색기업 지정절차는 신청(기업) $\rightarrow$ 현지심사(지방 자치단체, 환경청) $\rightarrow$ 심사단 심사(외부전문가 포함) $\rightarrow$ 최종평가(환경청 $) \rightarrow$ 환경부 지정 등의 순서로 진 행되는데, 3 단계의 평가를 거친다.

1 단계 평가에서는 기업에서 환경청에 녹색기업 지 정 신청서 제출, 오염물질 채취·검사 등 현지 확인을 실시하고, 환경법령 위반여부 의견조회 등 신청자격 의 제한요건 검토, 환경관리 일반현황에 대한 환경청 평가 결과가 일정수준(80점) 이상인 경우 녹색기업 심사단을 구성하여 현지실사를 실시한다. 2단계 평가 에서는 환경청에서 '필수평가지정항목'에 대하여 세 부평가기준에 따라 평가를 실시하고 그 결과를 심사 단에 통보, 환경청에서 위촉하여 운영하고 있는 녹색 기업 심사단 중 분야별 1 인 이상(6 10명) 선정하여 현지실사 및 평가 실시, 심사단 평가결과가 일정수준 이상인 경우 평가결과 및 종합의견서를 첨부하여 환 경부장관에게 녹색기업 지정을 요청한다. 3 단계 평가 에서는 환경부 내 환경친화기업 지정여부에 대한 의 견조회를 거쳐 녹색기업 지정 요청에 대한 검토결과
를 유역환경청에 통보한다.

녹색기업 지정제의 평가기준은 중소기업 및 비제 조업 분야 참여 유도를 통한 녹색기업 지정제 활성화 를 위하여 규모별·업종별 녹색기업 평가기준을 적용 하고 있다. 또한 제조업과 비제조업의 2 개 기준으로 평가해 온 기존의 업종별 평가기준을 총 14 개 기준으 로 세분화함으로써, 각 산업 업종별 특성을 반영한 평가기준을 마련했음. 제조업의 경우 제조업 일반, 전기·전자, 제지, 플라스틱·고무·섬유, 자동차·기계, 식료품, 석유화학.금속 등 7 개 기준으로 구분하는 한 편, 비제조업의 경우 비제조업 일반·발전·건설·유통. 운송·금융·숙박 등 7 개 기준으로 구분하여, 기존에는 녹색기업에 대한 평가기준이 업종별 특성에 부합하지 않아 참여하지 못했던 기업들이 녹색기업 지정제에 적극 동참할 수 있도록 평가기준을 개선하고 있다.

녹색기업의 평가 심사기준을 살펴보면, 대기업의 제조업 일반기준시 녹색경영활동 450점 및 녹색경영 성과평가 250 점의 총 700 점 만점이다. 녹색경영활동 의 세부기준은 녹색 경영체제 구축현황(100점), 녹색 경영목표 수립 및 기업간 협력(50점), 자원·에너지(90 점), 온실가스-환경오염(140점) 항목으로 심사한다. 녹색경영 성과평가의 기준은 자원·에너지(120점), 온 실가스·환경오염(110점), 녹색제품·서비스(20점)을 적 용하고 있다 [15].

\section{3. 온실가스 감축컨설팅 우수기업 지정제} 제도화 방안

목표관리제 시행에 따른 온실가스 감축컨설팅 우 수기업 지정제의 제도화 방안을 모색하는 배경은 관 련 컨설팅 기업들이 대상기업의 감축목표를 달성하기 위하여 온실가스 감축시스템을 구축하고 실행하도록 유도하는데 주목적이 있다. 또한 온실가스 감축컨설 팅관련 산업의 활성화를 위해서도 온실가스 감축컨설 팅 우수기업 지정에 관한 제도적 틀을 제시하고자 한 다. 정부 정책의도가 제도수립과정에서 나타나기 위 해서는 먼저 제도적인 근거를 확보하고 이를 뒷받침 할 수 있도록 적용하는 방안을 마련할 필요가 있다고 하겠다.

이러한 제도화 방안은 김성진 [3], 석승우 [5], 이 창준 [8] 연구사례를 참조하여, 정부 및 에너지관리공 단 정책관계자를 비롯하여 $\mathrm{ESCO}$-에너지진단 및 온 실가스 감축컨설팅업계 관계자 등의 전문가단 자문을 통해 마련되었다. 즉, 온실가스 감축컨설팅 우수기업 
지정에 관한 방안이 원활하게 시행되기 위한 신청, 심사, 지정 및 취소 등 제도적 틀의 강구를 모색하였 다. 앞에서 살펴본 바와 같이 우수 $\mathrm{ESCO}$ 지정 및 녹 색기업 지정사례를 참조하여 온실가스 감축컨설팅 우 수기업 지정제 제도화 방안의 주요 논점은 평가절차 와 전담기관 및 평가기관의 설정, 평가기준의 검토 및 평가기관의 평가위원회 구성, 지정에 따른 인센티 브 부여 범위 등으로 요약할 수 있다.

\section{3-1. 우수기업 지정대상과 범위}

우수기업 지정대상은 목표관리제 시행에 따른 온 실가스 감축컨설팅 및 관련 산업 업체로, 최근 3 년간 계속하여 온실가스 감축컨설팅 등을 통해 온실가스 감축을 실현한 사업 수행실적이 있는 업체로 정할 수 있다. 예를 들면 온실가스 감축컨설팅의 범위는 에너 지진단, 온실가스 감축컨설팅 및 $\mathrm{ESCO}$ 분야 등으로 정의할 수 있다. 지정대상의 사업은 업체당 한 사업 으로 온실가스 감축을 실현한 실적이 있는 업체의 사 업실적으로 명확히 한정한다.

우수기업 지정대상의 자격요건은 최근 3년간 산업 통상자원부장관으로부터 자금지원 중단이나 주의 또 는 경고처분을 받은 사실이 없을 것, 최근 3 년간 공 공기관으로부터 입찰 및 계약이행 과정에서의 부정행 위로 인해 입찰참가자격 제한조치를 받은 사실이 없 을 것, 최근 3 년간 업체나 대표자가 부도 또는 파산 한 사실이 없을 것으로 정하되, 유효기간 중 상기 자 격요건에 미달될 경우 우수기업 지정이 취소되도록 한다.

\section{3-2. 우수기업 지정 평가절차}

우수기업 지정을 위한 신청자는 전담기관의 지정 기관 홈페이지 및 관련부서를 통해 신청서 및 구비서 류를 제출한다. 우수기업 지정대상 온실가스 감축컨 설팅기업의 신청자는 평가기관에 신청서 및 구비서류 를 제출해야 한다. 전담기관은 신청요건 및 신청서, 구비서류, 지정수수료 납부 등을 검토한 후 접수하여 신청서를 제출받은 날부터 45 일 이내에 지정여부를 결정해야 한다.

지정평가 의뢰받은 전담기관은 평가기관에 지정평 가를 의뢰하게 된다. 평가기관은 인증평가를 접수하 고 별도 대장에 관리하여야 한다. 평가기관은 평가위 원회를 구성하여 현장평가와 서류평가를 시행하여야
한다. 평가위원회는 평가위원단(Pool) 중에서 7인 이 상으로 구성할 수 있다. 평가위원회는 서류평가 시 필요한 경우 신청자에게 발표를 요청하고, 평가위원 장은 지정 종합평가표를 작성하여 평가기관에 제출하 게 된다. 평가기관은 평가결과를 전담기관에 송부하 고 지정 평가기준에 적합한 경우 지정을 추천하게 된 다.

우수기업 지정 확정은 전담기관이 우수기업 지정 평가위원회를 개최하여 지정대상에 대한 지정여부를 확정하고, 최종 확정된 결과를 신청자에게 안내하고 평가기관에 통보한다. 지정 확정결과에 이의가 있는 신청자는 결과 안내를 받은 날부터 30 일 이내에 전담 기관에 이의 신청할 수 있다. 전담기관은 지정이 확 정된 경우 신청자에게 우수기업 지정서를 발급하되, 소관 행정기관의 장 명의로 발급된다.

\section{3-3. 선정방법 및 세부평가기준}

\section{3-3-1. 선정방법}

선정방법은 서류심사와 현장심사 및 종합심사를 거치는데, 서류심사를 통해 평가항목 및 배점기준에 의한 정량적 심사를 통해 우수기업 지정규모의 3 배수 이내로 선정한다. 현장심사에서는 서류심사를 통과한 기업에 대해 현장방문을 통해 제출서류의 적합여부를 확인한다. 종합심사는 평가위원회에서 업체별 발표 내용을 참고하여, 종합심사 시에 세부평가기준에 의 거한 위원별 개별 평가를 실시한다. 이 때 서류심사 (현장심사 포함) 점수 $(50 \%)$ 와 지정위원회 종합심사 점수 $(50 \%)$ 를 기준으로 최종 우수기업을 선정한다.

우수기업 선정방안은 전체 기준에 대하여 매년 가 장 우수한 기업 1 개만 선정하는데, 온실가스 감축컨 설팅 관련분야의 최우수 기업에 수여한다는 취지에 가장 잘 부합되지만 대기업 위주로 선정될 우려가 제 기될 수 있다. 이에, 전체 기준에 대하여 매년 최우수 기업과 우수기업으로 구분하여 대기업부문과 중소기 업부문으로 각각 1 개씩 선정을 고려할 수 있다. 현재 지정대상 기업수가 많지 않은 상황의 고려가 필요가 있다. 중소기업의 온실가스 감축컨설팅 참여의지 제 고가 가능하나, 실제 참여기업수가 많지 않을 가능성 이 있는 상황에서 단기적으로 수상의 실효성이 저하 될 우려가 제기될 수 있다.

\section{3-3-2. 세부평가기준}

온실가스 감축컨설팅에 대한 우수기업의 평가기준 
Table 1. Evaluation Indicators for Certification Scheme of Consulting Company

\begin{tabular}{|c|c|c|}
\hline 평가분야 & 평가항목 & 평가요소 \\
\hline $\begin{array}{c}\text { 사업실적 } \\
\text { (30) }\end{array}$ & $\begin{array}{l}\text { •컨설팅 사업금액(10) } \\
\text { •컨설팅 사업건수(10) } \\
\text { •투자효율(10) }\end{array}$ & $\begin{array}{l}\text {-업체평균 컨설팅 사업금액에 대한 해당업체 비율 } \\
\text {-업체평균 사업건수에 대한 해당업체 비율 } \\
\text {-업체평균 사업금액당 온실가스 감축량 해당업체 비율 }\end{array}$ \\
\hline 고객만족도(20) & •획득 평점 & -에너지사용자로부터 직접 조사하여 획득한 점수 \\
\hline $\begin{array}{l}\text { 사업 타당성 } \\
\text { (20) }\end{array}$ & $\begin{array}{l}\text { •미달 시 대책(10) } \\
\text { •기술능력 실적(10) }\end{array}$ & $\begin{array}{l}\text {-사업목표(감축목표) 미달 시 대책의 명시 및 부합성 } \\
\text { •에너지진단사 자격취득 또는 정부 및 공단 등 교육 이수 }\end{array}$ \\
\hline $\begin{array}{c}\text { 경영상태 } \\
\text { (30) }\end{array}$ & $\begin{array}{l}\text { •부채비율(5) } \\
\text { •매출액 순이익율(10) } \\
\text { •유동비율(10) } \\
\text { •영업기간(5) }\end{array}$ & $\begin{array}{l}\text {-업체평균 부채비율에 대한 해당업체 비율 } \\
\text {-업체평균 매출액 순이 익율에 대한 해당업체 비율 } \\
\text { - 업체평균 유동비율에 대한 해당업체 비율 } \\
\text { - 기업등록 유지년수 }\end{array}$ \\
\hline
\end{tabular}

은 직접적인 사례나 참고할만한 평가기준이 없기 때 문에, 평가지표를 보다 구체적으로 기술하는 수준에 서 세부평가기준을 작성하는 것이 필요하다. 온실가 스 감축컨설팅에 대한 우수기업의 평가기준 설정방향 은 목표관리제 시행에 따른 온실가스 감축컨설팅 업 체를 대상으로 계속적으로 온실가스 감축컨설팅 등을 통해 우수한 온실가스 감축을 실현한 사업에 대해 지 정하는 제도의 도입 취지에 부합하는 목적 설정에 따 른 대안을 작성할 수 있다.

온실가스 감축컨설팅 우수기업의 평가기준(안) 설 정은 1) 사업 수행실적 관련 컨설팅 기업에 대한 상 대적 위치를 고려한 우수성, 2) 목표관리제 관리 대상 기업 및 사업장인 고객의 만족도, 3) 목표관리제 관련 목표달성측면의 보완이나 기술능력 배양 정도, 4) 목 표관리제 관련 컨설팅 기업의 안정적 경영상태 및 경 영지표에 대한 실적 평가 등을 전제하였다. 이러한 전제에 따라 업계 관계자 및 전문가 자문을 통해 사 업실적(30점), 고객만족도(20점), 사업타당성(20점), 경영상태(30점) 등 100 점 만점으로 설정하였다.

\section{3-4. 평가기관 지정}

온실가스 감축컨설팅에 대한 우수기업의 평가기관 지정과 관련한 지정요건은 녹색인증제 운영요령 [10] 을 참조할 수 있다. 이 요령에 의하면, 평가기관은 녹 색기술 및 녹색사업과 관련된 분야의 연구개발사업의 기획·평가 및 관리 전문기관으로서, (1) 「공공기관의
운영에 관한 법률 에 따른 준정부기관 또는 기타공 공기관, (2) 「국가연구개발사업 등의 성과평가 및 성 과관리에 관한 법률」에 따른 연구관리전문기관에 해 당하는 기관이어야 한다 [2].

기획재정부의 「2011년 공공기관 지정안」에 따르 면, 준정부기관 또는 기타공공기관으로 산업통상자원 부 소관·위탁집행형 준정부기관에 에너지관리공단, 한국에너지기술평가원이 지정되고, 기타공공기관에 한국에너지기술연구원, 에너지경제연구원이 지정되어 있다. 산업통상자원부 소속의 연구관리전문기관은 에 너지관리공단(위탁수행관리, 기타), 한국에너지기술평 가원(위탁수행관리) 등이 있다 [2].

온실가스 감축컨설팅에 대한 우수기업의 평가기관 지정과 관련하여 평가기관의 지정요건에 부합하는 기 관은 에너지관리공단, 한국에너지기술평가원, 에너지 경제연구원 등 3 개 기관이 해당된다. 이 기관 중에서 에너지관리공단이 평가기관의 지정요건에 부합된다 고 할 수 있다. 에너지관리공단은 직접 온실가스 감 축업무, 한국에너지기술평가원은 녹색기술사업.전문 기업 인증 관련업무, 에너지경제연구원은 온실가스 감축관련 연구업무를 담당하는 기관이다. 이 중에서 온실가스 감축업무를 담당하는 에너지관리공단이 평 가기관의 지정요건에 부합하는 것으로 판단된다.

\section{3-5. 평가위원회 구성}

평가위원회는 온실가스 감축컨설팅 우수기업 지정 
을 신청한 녹색 기술과 사업을 평가기준에 따라 평가 (현장평가 및 서류평가)하는 역할을 수행한다. 평가 시 평가위원단 중에서 7인 이상으로 평가위원회를 구 성하여 현장평가와 서류평가에 참여하게 된다. 평가 위원은 녹색인증제 운영요령을 참조하여 관계자 및 전문가가 포함되도록 선정하여야 할 것이다. 즉, (1) 산업계 : 박사학위 소지자 또는 석사(학사)학위 소지 자로서 해당분야 5년(7년) 이상 경력자, 또는 이사급 이상의 임원, (2) 학계 : 2 년제 대학 이상에서 전임강 사 이상의 교수, (3) 연구계 : 박사학위 소지자 또는 석사(학사)학위 소지자로서 해당분야 5년(7년) 이상 경력자, (4) 공무원 : 5 급 이상의 공무원, (5) 기타 : 평 가기관의 장이 제 1 호 내지 제 4 호와 동등한 자격(기술 사 포함)이 있다고 인정하는 자 등이다 [10].

평가위원의 위원단은 온실가스 감축컨설팅분야의 사업의 지정범위, 평가기준(사업실적, 고객만족도, 사 업타당성, 경영상태 등)을 고려하여 정해야 할 것이 다. 이 경우 이해관계자 참여 배제를 원칙으로 구성 할 필요가 있는데, 분야별 평가위원 선정 및 구성은 온실가스 감축컨설팅관련 우수기업 지정 평가를 위해 에너지진단, 온실가스 감축컨설팅, $\mathrm{ESCO}$ 분야 등 분 야별 평가위원 선정 및 구성이 필요하다.

\section{4. 요약 및 결론}

본고는 목표관리제 시행에 따른 대상기업의 온실 가스 감축 대응역량 제고 측면에서 관련기업의 감축 목표를 달성하기 위하여 온실가스 감축시스템을 구축 하고 실행하도록 유도하기 위한 방안의 하나로, 온실 가스 감축컨설팅 우수기업 지정 제도화 방안을 제시 하는데 목적이 있다. 이러한 제도화 방안은 온실가스 감축컨설팅 우수기업 지정에 관한 방안이 원활하게 시행되도록 정책 및 업계 전문가 자문을 통해 신청, 심사, 지정 및 취소 등 제도적 틀을 강구하는데 목표 를 두고 제시하였다.

온실가스 감축컨설팅 기업의 우수기업 지정대상과 범위는 에너지진단, 온실가스 감축컨설팅, $\mathrm{ESCO}$ 분 야 등으로 정할 수 있다. 지정대상의 사업은 업체당 한 사업으로 온실가스감축을 실현한 실적이 있는 업 체의 사업실적으로 한정한다. 다시 말해서 지정대상 은 목표관리제 시행에 따른 온실가스 감축컨설팅 및 관련 산업 업체로, 최근 3년간 계속하여 온실가스 감 축컨설팅을 통해 온실가스감축을 실현한 사업 수행실
적이 있는 업체로 정한다.

우수기업 지정대상의 자격요건은 1) 최근 3 년간 산 업통상자원부장관으로부터 자금지원 중단이나 주의 또는 경고처분을 받은 사실이 없고, 2) 최근 3년간 공 공기관으로부터 입찰 및 계약이행 과정에서의 부정행 위로 인해 입찰참가자격 제한조치를 받은 사실이 없 으며, 3) 최근 3년간 업체나 대표자가 부도 또는 파산 한 사실이 없는 등이다. 유효기간 중 상기 자격요건 에 미달될 경우 우수기업 지정이 취소될 수 있다. 우 수기업 선정방안은 매년 가장 우수한 기업 1 개만 선 정하거나, 매년 최우수 기업과 우수기업으로 구분하 여 대기업부문과 중소기업부문으로 각각 1 개씩 선정 하되, 현재 지정대상 기업수가 많지 않은 상황을 고 려한다.

세부평가기준은 관계 전문가의 자문의견에 의거해 초기단계 시점에서 목표관리제 시행에 따른 감축목표 달성과 관련 컨설팅 기업에 대한 상대적 위치를 고려 한 사업실적과 경영상태의 우수성 등 지표 평가를 중 시하는 데 주안점을 두어 설정하였다. 평가항목 설정 (안)은 사업실적(30점), 고객만족도(20점), 사업타당 성(20점), 경영상태(30점) 등 100점 만점으로 정하였 다. 평가결과 우수기업 지정에 따른 인센티브는 우수 기업 지정서 수여, 언론 및 공단 홈페이지를 통한 홍 보, 자금지원 시 우대 혜택을 부여할 수 있을 것이다. 본고에서는 컨설팅 우수기업 지정제에 대해 초기 시행단계에서 사업실적과 경영상태의 우수성 등 수행 실적을 평가하는 데에 주안점을 두어 제시하고 있다. 향후 일정기간 이후에는 목표관리제 시행이 본격화되 면서 에너지절약 및 온실가스 감축성과에 대한 평가 항목을 추가적으로 포함하여 감안하는 방향으로 보완 하는 것이 바람직할 것이다. 물론 이를 위한 온실가 스 감축관련 업계의 평가항목에 관한 선호의식 조사 가 필요하며, 조사결과를 바탕으로 온실가스 감축컨 설팅 우수기업 평가기준을 보완하기 위한 방안 마련 이 필요할 것이다.

\section{참고문헌}

1. 국가법령정보센터, 저탄소 녹색성장 기본법, 2013.

2. 기획재정부, 2011년도 공공기관 지정, 보도자료, 2011.1.24.

3. 김성진, 관광분야 녹색인증 시행방안 연구, 한국 
문화관광연구원, 2010.

4. 문승재, 국내 환경컨설팅 현황과 전망, 환경정보, 3·4월호, 2009

5. 석승우, 환경친화기업 지정제도 발전방안, 환경 부, 2008.

6. 에너지관리공단, $\mathrm{ESCO}$ 사업 추진현황, 내부자료, 2013.6.

7. 에너지관리공단, 우수 $\mathrm{ESCO}$ 인증안내, 2008.

8. 이창준, 녹색경영 중소기업 지정을 위한 평가매 뉴얼 개발, 중소기업청, 2009.

9. 임기추, 온실가스-에너지 목표관리제 시행에 따른 신산업 육성 및 활성화방안 연구, 에너지경제연 구원, 2011.

10. 지식경제부 외, 녹색인증제 운영요령, 2013.

11. 지식경제부, 산업·발전분야 관리업체 2012년 온 실가스-에너지 목표, 보도자료, 2011.10.11.

12. 지식경제부, 산업·발전분야 온실가스.에너지 목표 관리업체 고시, 보도자료, 2011.7.29.

13. 지식경제부, 온실가스-에너지 목표관리제도 본격 추진, 보도자료, 2011.7.21.

14. 지식경제부, 산업.발전분야 온실가스-에너지 목표 관리업체 374 개 지정, 보도자료, 2010.9.28

15. 환경부, 녹색기업 지정제도 운영규정, 2011.7.

16. 환경부, 녹색기업 지정현황, 2012.10. 